\title{
Unintended Pregnancy among Unmarried Adolescents and Young Women in Anambra State, South East Nigeria
}

\author{
Amobi Ilika and Igwegbe Anthony ${ }^{2}$
}

\begin{abstract}
This study identified the characteristics and factors influencing unintended pregnancy among unmarried young women in a rural community in south-east Nigeria. One hundred and thirty six unmarried teens with unintended pregnancy attending a Christian hospital in Ozubulu, a rural community in south-east Nigeria, from January 1998 to December 2001 were included in the study. Information was obtained using a semi-structured questionnaire and in-depth interview. Over $75 \%$ of the girls had their first sexual intercourse by 19 years, and over $69 \%$ had multiple partners. Over $95 \%$ had sex for economic reasons and exchanged sex for money or gifts. Only $13.5 \%$ ever used condoms. Ninety seven per cent suffered violence such as beating and verbal abuse from family members because of the pregnancy. Most of the adolescents or young women experienced major stressors, most importantly school and job termination, partner's negative attitude, religious sanction, discrimination and stigmatisation as a result of the unintended pregnancy. Unmarried pregnant adolescents or young women have particular health and psychosocial problems. Stakeholders in adolescent health, namely, parents, teachers, religious groups and health care providers, should recognise these problems and advocate for the provision of appropriate care and youth-friendly services to help youths navigate through these problems. (Afr J Reprod Health 2004; 8[3]:92-102)

RÉSUMÉ

Grossesse non-désirée chez les adolescentes non-mariées et chez les jeunes femmes dans l'Etat d'Anambra, au sud du Nigéria. Cette étude identifié les caractéristiques et les facteurs qui influencent la grosses non-désirée chez les jeunes femmes non-mariées dans une communauté rurale au sud-est du Nigéria. Cent-trente-six adolescentes non-marriées qui étaient enceintes des enfants non-désirés, qui fréquentaient un hôpital chrétien à Ozubulu, une communauté rurale au sud-est du Nigéria, entre janvier 1998 et décembre 2001, ont fait partie de l'étude. Nous avons recueilli des renseignements à l'aide d'un questionnaire semistructuré ainsi que d'une interview en profondeur. Plus de $75 \%$ des filles ont leur premier rapport sexuel à l'âge de 19ans et plus de 69\% avaient multiple partenaires. Plus de 95\% avaient des rapports sexuels pour des raisons économiques et avaient échangé le sexe pour l'argent ou pour des cadeaux. Seuls $13,5 \%$ avaient jamais utilisé les préservatifs. Quatre-vingt-sept ont subi la violence tels que la correction et l'abus verbal de la part des membres de famille pendant la grossesse. La plupart de ces adolescentes ou jeunes femmes ont subi beaucoup de tension, surtout l'arrêt de scolarisation et du travail, l'attitude négative du partenaire, la sanction religieuse, la discrimination et la stigmatisation à cause de la grossesse non-désirée. Les adolescentes ou les jeunes femmes enceintes non-mariées ont des problèmes psychologiques et de santé particuliers. Tous ceux qui sont concernés par la santé adolescente, à savoir les parents, les enseignants, les groupes religieux et les dispensateurs du soin médical, doivent reconnaître ce problème et doivent plaidoyer pour le soin approprié et les services qui favorisent la jeunesse pour aider les adolescentes à naviguer entre les écueils. (Rev Afr Santé Reprod 2004; 8[3]:92-102)
\end{abstract}

Department of Obstetrics and Gynecology, Nnamdi Aziikiwe University, Nnewi, Nigeria 


\section{Introduction}

Pregnancy among unmarried adolescents or young women is a serious reproductive health problem especially in developing countries. More than 14 million adolescent women give birth each year. A large proportion of these pregnancies is unwanted, and it is estimated by the World Health Organization (WHO) that as many as 4.4 million abortions are sought by adolescent girls each year. ${ }^{1}$

Every year, almost one million teenage girls become pregnant in Nigeria and many of these pregnancies are unintended and unwanted.

The health and social consequences of unwanted or unintended teenage pregnancy have been very much described. ${ }^{1-7}$ These include, among others, increased risk of maternal death, pregnancy and birth-related complications such as excessive bleeding, anaemia, obstructed labour, stillbirth and infant death.

The socio-economic consequences include education and job termination, stigmatisation, and loss of self-esteem and perpetuation of the poverty trap and cycle. With the rampaging HIV/AIDS epidemic and other sexually transmitted diseases in the sub-Saharan region, unintended teenage pregnancy among unmarried young women has become a disturbing public health problem, not only because it is a risk factor for HIV/AIDS transmission, but also because it posses a serious adolescent reproductive health and development challenge.

Knowledge and understanding of the factors and dynamics that characterise teenage unwanted pregnancies in the region should have an impact on policy and programme to meet the challenges. These challenges include the provision of easily accessible reproductive health youth-friendly services, sexuality education in schools and advocacy with all stakeholders parents, teachers, church leaders and health care providers to support programmes to reduce the problem of unwanted pregnancy among young people.

This study was therefore conducted to identify the factors and characteristics of teens with an unwanted pregnancy at a rural hospital in south-east Nigeria from January 1998 to December 2001. The implication for adolescent reproductive health in the area is further discussed.

\section{Method \\ Study Background}

The study was conducted at Christian Hospital located in Ozubulu, headquarters of Ekwusigo Local Government Area in Anambra State of Nigeria. Its catchment area covers over five local government areas in the heart of Igboland. The customs and marriage patterns largely represent that of the Igbo tribe in southeast Nigeria. Most of the inhabitants are Christians.

The customs and tradition of the area do not permit pregnancy before and outside marriage. Girls are expected to remain virgins until they get married. At marriage, if the husband confirms that the girl is a virgin, he would declare her as kwu akwu, meaning that she was sexually intact. She had not had sexual intercourse before the marriage. The young husband would give gifts to the girl for preserving her virginity and to the girl's mother for giving her daughter good training. The young men on the other hand are not traditionally expected to be virgins before marriage.

Although monogamy and polygamy are in common practice, there are other 
acceptable marriage practices. For example, a woman who has no child or has only female children could marry a younger woman who will bear male children for the family in order to keep the husband's family name. This could be done irrespective of whether the husband is dead or living. An old man may also marry a young girl to bear male children for him if he had no male children in his earlier marriage, even with the full understanding that he would most unlikely be the biological father of the children.

Also, a man who perceives himself or his wife to be infertile could marry a pregnant young woman so that he can own the baby, since he is assured of the woman's fertility. Parents of mentally impaired male children could also marry a wife for such children.

Unfortunately, however, the victims of these types of marriages are most often unmarried young women with unintended pregnancies. Child adoption is very rarely practised, and it occurs only among educated men living in urban centres.

Christian Hospital was chosen for the study because of its accessibility to the community, as it is situated in the heart of Ozubulu town, and also offers reproductive health services.

The author works in the hospital, a factor considered advantageous for the collection of data on such sensitive reproductive health issue being considered. For the three-year period (January 1998 to December 2001) one 155 young unmarried women with unwanted and unintended pregnancy attended the hospital for antenatal care. This figure may however not be fully representative as some of the unmarried pregnant women or adolescents might have sought care in other hospitals in and outside the area. It is common practice in the area for mothers of pregnant teens to send them to live with relations in distant urban cities for antenatal care as soon as the pregnancy is discovered. They do this to conceal the pregnancy and save the family from embarrassment. Others may have procured abortion elsewhere and would not seek antenatal care.

The nature of the interview was explained to the potential participants and their consent obtained. One hundred and thirty six of the 155 unmarried pregnant young women participated in the study. Eleven out of the remaining 19 refused to consent, while the other eight attended antenatal clinic once and were interviewed once but were not present for a second interview to crosscheck and validate information given during their first visit.

Two interviews were conducted for each woman using the same questionnaire; one at first visit or contact and the second at subsequent visit. This was to validate and crosscheck earlier information. The researcher believed that the young pregnant adolescents would have developed more confidence in the doctor and health workers to enable them to give more accurate information about the circumstances of the pregnancy at their second visit.

Information was elicited from the study subjects about their sexual behaviour and present pregnancy using a semi-structured questionnaire. All the interviews were conducted at the hospital.

In-depth interview was conducted with ten of the young women. Every tenth pregnant adolescent or woman who attended the clinic on a second visit was chosen for the 
in-depth interview until a total of ten were interviewed. For the ten selected girls, both the questionnaire and in-depth interviews were held simultaneously. Both interviews sought information on sexual activities, sexual partners, use of contraception, attitude towards present pregnancy, parents' and partners' attitude, and future preventive plans.

\section{Result}

One hundred and thirty six adolescents or young women completed the study, out of a total of 155 qualified women, giving a response rate of $90.7 \%$. The result is presented in Tables 13. Out of the 136 subjects, $43.4 \%$ were between the ages of 17 and 19 years. More than $40 \%$ were students and over $85 \%$ possessed or enrolled for secondary education. Within the sample, a higher percentage of pregnant teens were students than unskilled workers, although the difference was not statistically significant. Also a higher percentage of the teens with secondary education than those with primary education were pregnant. This difference was statistically significant.

About $70 \%$ of the subjects had their first sexual experience or intercourse by age 19 years and over $69 \%$ had multiple partners.

Over $98 \%$ had sex for material gains. Such material gains include money, clothing, food and drinks, and free bus rides to school. About $25 \%$ had had sexually transmitted diseases in the past, while $17.6 \%$ had been pregnant before. Only $13.2 \%$ had ever used condoms. About $88 \%$ of the girls felt extremely worried with their pregnancy, and $59.6 \%$ had attempted to terminate the pregnancy.
Major stressors were fear of stigmatisation, partner's negative reaction, and the fear of school and job termination, forced marriage by their parents who would not want an eloyi, a traditionally illegitimate child. Other stressors were parental disappointment based on the fact that their daughter would have to leave school, and that other villagers would consider the parents as having failed to give their child proper moral upbringing. In addition, the mother would loose the gift usually offered by the daughter's husband at marriage if the daughter were to be confirmed a virgin by the man after marriage. Suprisingly, only $8.8 \%$ considered the fear of STDs and HIV/AIDS as a stressor.

Ninety seven per cent of the girls experienced violence from family members during the pregnancy as a reaction to the pregnancy. About $57 \%$ experienced violence such as flogging and slaps, while over $97 \%$ experienced verbal violence such as abuses, severe reprimands and curses. About 17\% were forced to marry a man whom they did not like by their parents. Such undesirable marriages have been described somewhere in this text.

Analysis of the in-depth interview revealed that the key motivation for sex was material gains. The major gift was money to supplement school fees and buy other necessities such as cosmetics and wearing apparels. Other gifts include clothings, snacks, food and drinks, and free rides to school or work place.

Most of the partners were much older men, a situation that made it difficult for the girls to negotiate safe sex.

Fifty nine per cent of the adolescents or young women who sought termination of pregnancy tried local concoctions. Most often 
used items were Andrew's liver salt, hot pepper soup, hot drinks and ergometrine tablets or injection bought from patent medicine stores. In some cases, local medicine men also inserted local herbs into the vagina to induce abortion.

Most often the girls confided in their peers for fear of their parents' violent reaction. The women's greatest stressor were rejection by their partners, who often refused to admit being responsible for the pregnancy, and denied them marriage and financial support in spite of past expressions of love and promises.

Most of the adolescents who were students expressed their desire to go back to school after the pregnancy, but would prefer a new school because going back to their former schools would affect their self-esteem. They imagined that they would be taunted and looked down on by fellow students and teachers.

Table 1 Socio-Demographic Characteristics of Respondents $(\mathbf{N}=136)$

\begin{tabular}{lrc}
\hline & $\mathbf{n}$ & $\%$ \\
\hline Age (years) & 1 & \\
$<14$ & 8 & 0.7 \\
$14-16$ & 59 & 5.9 \\
$17-19$ & 42 & 43.4 \\
$20-22$ & 26 & 30.9 \\
$>22$ & & 19.1 \\
Occupation* & 56 & \\
Students & 42 & 41.2 \\
Unskilled/casual workers & 13 & 30.9 \\
Domestic servant/maids & 7 & 9.6 \\
Skilled workers & 8 & 5.1 \\
Unemployed & & 13.2 \\
Educational status** & 18 & \\
$\quad$ Primary & 114 & 13.2 \\
Secondary & 4 & 83.8 \\
Tertiary & & 3.0 \\
\hline
\end{tabular}

*Students versus unskilled worker not significant $(p>0.05)$ **Primary versus secondary Significant $(p<0.05)$ 
Table 2 Sexual History of Respondents $(\mathbf{N}=136)$

\begin{tabular}{|c|c|c|}
\hline & $\mathbf{n}$ & $\%$ \\
\hline \multicolumn{3}{|l|}{ Age at first intercourse (years) } \\
\hline$<14$ & 6 & 4.4 \\
\hline $14-16$ & 42 & 30.8 \\
\hline $17-19$ & 50 & 36.8 \\
\hline 2022 & 36 & 26.5 \\
\hline$>22$ & 2 & 1.5 \\
\hline \multicolumn{3}{|l|}{ No of partners } \\
\hline Single & 42 & 30.9 \\
\hline Multiple & 94 & 69.1 \\
\hline Ever had STD & 35 & 25.7 \\
\hline Ever been pregnant & 24 & 17.6 \\
\hline Ever had abortion & 8 & 5.9 \\
\hline All time contraceptive use & 18 & 16.2 \\
\hline \multicolumn{3}{|l|}{ Reasons for having sex } \\
\hline Self-satisfaction & 28 & 20.6 \\
\hline Material gains & 134 & 98.5 \\
\hline Coercion & 19 & 14.0 \\
\hline Experimentation & 28 & 20.6 \\
\hline Misleading information & 37 & 27.2 \\
\hline Peer influence & 29 & 21.3 \\
\hline Promise of marriage & 18 & 13.2 \\
\hline
\end{tabular}


Table 3 Reactions to the Pregnancy by Respondents

\begin{tabular}{|c|c|c|}
\hline Adolescents' reaction & $\mathbf{n}$ & $\%$ \\
\hline \multicolumn{3}{|l|}{ Degree of worry } \\
\hline Worried & 6 & 4.4 \\
\hline Very worried & 10 & 7.4 \\
\hline Extremely worried & 120 & 88.2 \\
\hline \multicolumn{3}{|l|}{ Method of reporting to clinic } \\
\hline Self-reporting & 12 & 8.8 \\
\hline Brought in by relations & 124 & 91.2 \\
\hline \multicolumn{3}{|l|}{ Major stressors } \\
\hline Fear of stigmatisation & 134 & 98.6 \\
\hline Parent disappointment & 130 & 95.6 \\
\hline School expulsion & 56 & 41.2 \\
\hline Religious sanctions & 72 & 52.9 \\
\hline Partner's negative reaction & 128 & 94.0 \\
\hline Fear of STD/AIDS & 12 & 8.8 \\
\hline \multicolumn{3}{|l|}{ Parents' / relations' reactions } \\
\hline Verbal violence & 132 & 97.1 \\
\hline Physical violence & 78 & 57.4 \\
\hline Forced marriage & 24 & 17.6 \\
\hline
\end{tabular}

The young women suggested that the best way to avoid unintended pregnancy in future would be abstinence from sex. They considered the use of condoms impracticable because it is unacceptable to their parents and religion, which insist on premarital abstinence from sex. They feared that if their parents were to find condoms in their rooms or bags they would punish them. Also condoms are not easily accessible, and to negotiate to buy condoms from local medicine shops attracts branding the young unmarried adolescent as promiscuous. They rather preferred to use emergency contraception, which they understood to be a drug they could take immediately after sex to prevent getting pregnant.

Coerced or forced marriage was a recurrent issue expressed by the young women or adolescents in the in-depth interview. One of the young women who was forced into such marriage described it as 
"pressure marriage" not only because it was against her wish but also because the men married the pregnant young women for children and not for the love they had for them. Also, the marriage ceremony is usually not elaborate, and the customary gifts offered the bride are often omitted. Parents of girls with unwanted pregnancy usually want them to marry into these "pressure marriages" to avoid stigmatisation, and to save the baby from the cultural problem of paternity and patrilineage with the associated discrimination and denial of right of inheritance.

\section{Discussion}

This study revealed that unmarried teenage pregnant girls in the study area have peculiar problems, which include discrimination, violence and psycho-social stress and forced marriage. They were also involved in highrisk sexual behaviour for unwanted pregnancy, unsafe abortion and STDs including HIV/AIDS.

Over $30 \%$ of the girls had their first sex at 14-16 years while over $70 \%$ had their first sex during adolescence (10-19years). Early sexual debut among adolescents had been observed by Anate in Ilorin, Nigeria ${ }^{8}$, and in other studies elsewhere. ${ }^{2,9,11}$

Sexual intercourse with multiple partners and under-utilisation of condom or protective barriers are high-risk factors especially for HIV/AIDS, which is presently ravaging the region. These high-risk sexual behaviours have been extensively reported in other studies. Since unprotected sexual relationships place adolescent girls at risk for unwanted pregnancy and both girls and boys at risk for STDs including HIV/AIDS they need not only preventive services, but also youth-friendly health services including diagnosis, treatment, information and counselling. ${ }^{1}$

Sex for money or material reasons is a prevailing disturbing practice very much observed in developing countries. In Malawi, two third of girls who reported having sexual intercourse were accepting money or gift for sex. ${ }^{10}$ Such trends have been reported by other studies in Africa. ${ }^{11,12}$

It is suggested that the poverty situation, unemployment, under-employment and poor remuneration of the employed, and the poor financing of schools are key factors that fuel sex for money among teenage girls.

Poor funding of schools has resulted, among others, in accommodation and feeding problems for students. Many students who cannot be accommodated in school hostels or who cannot afford to pay boarding fees rent cheaper living rooms in the school suburb, where five or more of them stay in a room and share the cost. This situation exposes them to sexual exploitation in order to meet basic daily housing and living needs.

The young women who participated in the in-depth interview said most of their sex partners were people very much older than them. These men would usually be able to provide their material needs, a situation that puts the girls in a great disadvantage to negotiate sex. Other studies have made similar observations. ${ }^{9,10,12}$

Over $27 \%$ of the girls attributed misleading information as contributing to their getting pregnant. Such misleading information is often obtained from 
uninformed peers and medical quacks. Confusing and misleading information on safe period, painful menses, puberty maturational problems and emergency contraception were mentioned by the girls as major problems in the in-depth interview.

This underlies the need for sexuality education at the family and school levels. Further studies are however needed to determine the nature and magnitude of the false information so that they can be particularly addressed in health education programmes.

Almost all the girls suffered severe psychological and mental stress. Major stressors were fear of stigmatisation, parent disappointment, partners' negative reaction, religious ostracisation and school expulsion. Health care providers should therefore recognise this and offer appropriate counselling to both the young women and their parents to minimise the effect of the stress.

Discriminatory attitude toward unmarried teenage pregnant girls is an important issue that need to be addressed in adolescent reproductive health. This observation is in keeping with that of Igwegbe and Udigwe. ${ }^{5}$

In many countries girls who become pregnant are not allowed to continue to attend school. It is reported that in Kenya, an estimated 10,000 girls a year leave school because of pregnancy. ${ }^{1,13}$ It is an unwritten policy in Nigeria that pregnant school girls have to leave school. Even before official expulsion, most students would often had left school because of feelings of shame.

School policies that promote expulsion of pregnant girls, and church policies that put sanctions on pregnant girls are gender-based discriminations that not only violate the girls' human rights, but are likely to push young girls to seek unsafe abortions especially in countries where there is no access to safe abortion.

Male partners are often insulated from sanction. The young women had expressed denial and negative attitude by their male partners as very painful stressors. Support from male partners is likely to reduce mental stress on the girls. Appealing to the males to be empathic enough to admit and accept responsibilities for pregnancy which they are responsible for should be part of our reproductive health education.

Almost all the girls suffered genderbased violence from parents or relations and over $17 \%$ were forced to marry somebody against their will. Violence and forced early marriage affect physical and mental health and will adversely affect marriage and family stability. It will also affect partner fidelity with implications for STD/HIV prevention. Violence by family members may lead to serious physical injury, contemplation of suicide, it may affect communication between young adolescents and their parents, and erode trust and confidence. Forced early marriage will perpetuate the poverty cycle because the young women or adolescents are least likely to have gainful employment because of uncompleted education and early childbearing.

More than half of the young women attempted to terminate the pregnancy. Studies in Kenya showed that $47 \%$ of all young people below the age of 20 years who got pregnant while in school resorted to 
abortion. ${ }^{14}$ This follows the generally observed trend in many countries. ${ }^{12}$ The method they adopted to do this were quite unsafe and unsuccessful and included use of local concoctions such as hot pepper soup, hot drinks and injections from quacks. This suggests that teenage unmarried pregnant girls are a high-risk group for unsafe abortion. It further underlies the need for youthfriendly health services where young people would be confident and able to obtain care, information and counselling including contraceptive service.

\section{Conclusion}

Unmarried young pregnant women or adolescents show high-risk sexual behaviour for unwanted pregnancy, unsafe abortions, sexually transmitted diseases and HIV/AIDS. They have particular problems such as discrimination by families, school, church and society. Health planners and providers should recognise these peculiar problems in planning and implementing youth reproductive health services.

Stakeholders in adolescent health should in addition to providing preventive and rehabilitative youth-friendly services advocate for the elimination of discrimination and violence against unmarried pregnant girls. Health programmes and policies that will help young people navigate through reproductive health problems such as lifeskill education, poverty eradication and sexuality education should be included in inschool and out-of-school youth programmes.

\section{REFERENCES}

1. UNFPA. The State of the World Population 1999. New York: United Nations Population Fund, 30.

2. Action Health Incorporated. Meeting the Sexual and Reproductive Health Needs of

Young People in Nigeria. A Guide for Action.

Lagos: Action Health Incorporated, 1999, p 1.

3. WHO. Adolescent Sexuality and Reproductive Health Training Manual and Facilitator's Guide. WHO / FMSH / UNFPA 1999, 16-19.

4. Margaret P Battin. Adolescent pregnancy, when it is a problem, what is the solution? Reprod Health Matters 1996; 8: 1-10.

5. Igwegbe $\mathrm{AO}$ and Udigwe GO. Teenage pregnancy: still an obstetrics risk. $J$ Obstet Gynaecol2001;21(5): 478-481.

6. Anandalakshmy PN and Bucksheek. Teenage pregnancy and its effect on maternal and child health: a hospital experience. Ind JMed Sci47: 8-11.

7. Bacci A, Manhica GM, Machungo F, Bugalho A and Cuttini M. Outcome of teenage pregnancy in Maputo, Mozambique. InterJ Gynaecol Obstet 40: 19-23.

8. Anate M. Illegal abortion in Ilorin. Nig MedPract 11:41-44.

9. UNDP/UNFPA/WHO/World Bank. Sexual behaviour of growing people. Prog Hum Reprod Res 1997; 41:1. 


\section{African Journal of Reproductive Health}

10. Pathfinder/Futures/USAID. Focus on Young Adult: Advancing Young Adult Reproductive Health: Actions for the Next Decade. Washington DC: Pathfinder / Futures/USAID, 2001,p6.

11. Ntsiki Manzini. Sexual initiation and childbearing among adolescent girls in Kwazulu Natal, South Africa. Reprod Health Matters 2001;9(17): 44-51.

12. Vibeke Rasch, Margrethe Silberschmidt, Yasinta Mchumvu and Vumitia Mmary. Adolescent girls in illegally induced abortion in Dar es Salaam; the discrepancy between sexual behaviour and lack of access to contraception. Reprod Health Matters 2000; 8(15): 52-62.

13. Charles Nzioka. Perspectives of adolescent boys on the risk of unwanted pregnancy and sexually transmitted infections in Kenya. Reprod Health Matters 2001;9(17): 108-117.

14. Eunice Kamara. Reproductive and sexual health problems of adolescent girls in Kenya a challenge to the Church. Reprod Health Matters 1999; 7(14): 130-133. 